\title{
Carpal tunnel syndrome in the mucopolysaccharidoses and related disorders
}

\author{
J E Wraith, S M Alani
}

\section{Abstract}

Eighteen patients with various mucopolysaccharidoses or mucolipidosis III were studied electrophysiologically to determine the presence or absence of carpal tunnel syndrome. In 17 patients this was clearly demonstrated, the only exception being a boy with mucopolysaccharidosis II, age 6 months at testing. All patients had a remarkable lack of symptoms.

Carpal tunnel syndrome is a very common complication of the mucopolysaccharidoses and mucolipidosis III and should be actively looked for in affected patients. Early diagnosis and treatment offer the best chance of a good response to surgery.

The mucopolysaccharidoses are a group of inherited disorders caused by a deficiency of specific lysosomal enzymes. The enzyme deficiency causes interference with cellular function because of excessive accumulation within the cells of partially degraded glycosaminoglycans, which are also excreted to excess in the urine of affected patients. ${ }^{1}$ Mucolipidosis III is a related disorder caused by an inherited deficiency of the enzyme necessary for complete post-translational processing of lysosomal hydrolases. The clinical features produced by this enzyme deficiency mimic those of some of the mucopolysaccharidoses. ${ }^{23}$

Carpal tunnel syndrome is the commonest of the entrapment neuropathies, but it is rare in childhood. It is known to occur in association with the mucopolysaccharidoses or muco- lipidosis III, as well as other systemic disorders. ${ }^{4-10}$

A number of the patients with one of the mucopolysaccharidoses or mucolipidosis III are mildly affected by their disease and of normal intelligence, and these patients may have a good prognosis in terms of life expectancy. The loss of thumb function due to carpal tunnel syndrome can be a severe handicap especially as the skeletal dysplasia commonly present can also lead to restricted hand mobility.

We present a study on the incidence and age of onset of carpal tunnel syndrome in a group of 18 patients with one of the mucopolysaccharidoses or mucolipidosis III attending the Manchester mucopolysaccharidoses clinic.

\section{Patients and methods}

Eighteen patients with various types of mucopolysaccharidosis or mucolipidosis III were studied. The age at testing and results of electrophysiological studies are shown in the table.

All patients had a standard neurological examination. Sensation over the territory of the median nerve was assessed by the patients' ability to appreciate pinprick and being touched lightly with cotton wool in those who were old enough to cooperate with sensory testing.

Nerve conduction studies were performed using a Medelec MS91 electromyelography system. Median and ulnar sensory action potentials were recorded with surface electrodes placed over the median or ulnar nerves at the
Royal Manchester Children's Hospita Willink Biochemica Genetics Unit J E Wraith

Department of Neurophysiology S M Alani

Correspondence to: Dr J E Wraith, Willink Biochemical Genetics Unit, Royal Manchester Children's Hospital, Manchester M27 1HA. Accepted 2 May 1990
Electrophysiological results

\begin{tabular}{|c|c|c|c|c|c|c|c|c|c|}
\hline \multirow{2}{*}{$\begin{array}{l}\text { Patient } \\
\text { No }\end{array}$} & \multirow{2}{*}{$\begin{array}{l}\text { Age } \\
\text { (years) }\end{array}$} & \multirow[t]{2}{*}{ Sex } & \multirow[t]{2}{*}{ Diagnosis: } & \multicolumn{3}{|c|}{ Distal motor latency (ms) } & \multicolumn{3}{|c|}{ Sensory action potential (ms) } \\
\hline & & & & Right & Left & $\begin{array}{l}\text { Mean }(S D) \\
\text { normalt }\end{array}$ & Right & Left & $\begin{array}{l}\text { Mean }(S D) \\
\text { normalt }\end{array}$ \\
\hline $\begin{array}{l}1 \\
2 \ddagger \\
35 \\
4 \\
5 \\
6 \\
7 \\
8 \\
9 \\
10 \\
11 \\
12 \\
13 \\
14 \\
15 \\
16 \\
17 \\
18\end{array}$ & $\begin{array}{c}1 \cdot 2 \\
9 \\
9 \\
7 \\
8 \\
10 \\
9 \\
16 \\
0 \cdot 5 \\
1 \cdot 7 \\
2 \cdot 5 \\
3 \\
25 \\
16 \\
8 \\
9 \\
10 \\
14\end{array}$ & $\begin{array}{l}\mathbf{M} \\
\mathbf{M} \\
\mathbf{M} \\
\mathbf{F} \\
\mathbf{M} \\
\mathbf{F} \\
\mathbf{F} \\
\mathbf{M} \\
\mathbf{M} \\
\mathbf{M} \\
\mathbf{M} \\
\mathbf{M} \\
\mathbf{M} \\
\mathbf{F} \\
\mathbf{F} \\
\mathbf{F} \\
\mathbf{M} \\
\mathbf{F}\end{array}$ & $\begin{array}{l}\text { MPS I } \\
\text { MPS I } \\
\text { MPS I H } \\
\text { MPS I } \\
\text { MPS I S } \\
\text { MPS I } \\
\text { MPS I S } \\
\text { MPS I S } \\
\text { MPS II } \\
\text { MPS II } \\
\text { MPS II } \\
\text { MPS II } \\
\text { MPS II } \\
\text { MPS VI } \\
\text { ML III } \\
\text { ML III } \\
\text { ML III } \\
\text { ML III }\end{array}$ & $\begin{array}{l}4 \cdot 6 \\
3 \cdot 4 \\
\text { Absent } \\
5 \cdot 0 \\
\text { Absent } \\
\text { Absent } \\
\text { Absent } \\
4 \cdot 8 \\
2 \cdot 2 \\
6 \cdot 8 \\
\text { Absent } \\
4 \cdot 6 \\
\text { Absent } \\
8 \cdot 5 \\
2 \cdot 6 \\
\text { Absent } \\
\text { Absent } \\
3 \cdot 8\end{array}$ & $\begin{array}{c}4 \cdot 6 \\
3 \cdot 1 \\
\text { Absent } \\
2 \cdot 2 \\
\text { Absent } \\
\text { Absent } \\
\text { Absent } \\
10 \\
2 \cdot 0 \\
6 \cdot 0 \\
\text { Absent } \\
5 \cdot 4 \\
\text { Absent } \\
6 \cdot 6 \\
2 \cdot 9 \\
\text { Absent } \\
\text { Absent } \\
\text { Absent }\end{array}$ & 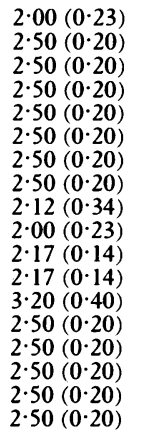 & $\begin{array}{l}2 \cdot 6 \\
\text { Absent } \\
\text { Absent } \\
\text { Absent } \\
\text { Absent } \\
\text { Absent } \\
\text { Absent } \\
\text { Absent } \\
1 \cdot 4 \\
2 \cdot 2 \\
\text { Absent } \\
3 \cdot 2 \\
\text { Absent } \\
\text { Absent } \\
\text { Absent } \\
\text { Absent } \\
\text { Absent } \\
\text { Absent }\end{array}$ & $\begin{array}{l}3 \cdot 0 \\
\text { Absent } \\
\text { Absent } \\
1 \cdot 2 \\
\text { Absent } \\
\text { Absent } \\
\text { Absent } \\
3 \cdot 8 \\
1 \cdot 2 \\
3 \cdot 1 \\
\text { Absent } \\
2 \cdot 4 \\
\text { Absent } \\
4 \cdot 6 \\
\text { Absent } \\
\text { Absent } \\
\text { Absent } \\
\text { Absent }\end{array}$ & $\begin{array}{l}1.20(0.1) \\
1.06(0 \cdot 1) \\
1.06(0.1) \\
1.20(0.1) \\
1.06(0.1) \\
1.06(0.1) \\
1.06(0.1) \\
1.06(0.1) \\
1.20(0 \cdot 2) \\
1.20(0 \cdot 1) \\
1.10(0 \cdot 1) \\
1.10(0 \cdot 1) \\
0.90(0 \cdot 1) \\
1.06(0 \cdot 1) \\
1.06(0.1) \\
1.06(0 \cdot 1) \\
1.06(0 \cdot 1) \\
1.06(0.1)\end{array}$ \\
\hline
\end{tabular}

MPS I H: mucopolysaccharidosis type I, Hurler's syndrome; MPS I S: mucopolysaccharidosis type I, Scheie's syndrome; MPS II: mucopolysaccharidosis type II, Hunter's syndrome; MPS VI: mucopolysaccharidosis type VI, Maroteaux-Lamy syndrome; ML III: mucolipidosis type III, pseudo-Hurler polydystrophy.

tSee Cruz Martinez et al.

Bone marrow transplant $\ddagger$ at age 14 months; $\$$ at age $2 \cdot 3$ years (both at Westminster Children's Hospital). 
wrist separately after application of supramaximal stimuli of $0.1 \mathrm{~ms}$ duration at $1 /$ second to the index and little finger, respectively, using ring electrodes with the cathode proximal. Ten potentials were averaged and latency to onset, peak to peak amplitude, and sensory nerve conduction velocity were measured.

The median motor response was recorded over the abductor pollicis brevis with surface electrodes after supramaximal stimulation of the median nerve at the wrist and elbow. The latency to onset, the amplitude of the negative component of the motor response at each site, and the motor conduction velocity were measured.

The median sensory response was considered abnormal if the potential was absent, smaller, or its latency $1 \mathrm{~ms}$ or more longer than that of the ipsilateral ulnar sensory potential. The median motor velocity was considered abnormal if absent or its latency was outside the normal range for age. ${ }^{11}$

\section{Results}

No patient or parent reported symptoms suggestive of carpal tunnel syndrome, such as parasthesiae or nocturnal pain.

All patients with the exception of those under the age of 2 years at testing (patients 1,9 , and 10) had clear evidence of wasting of the thenar muscles as well as the typical 'claw hand' deformity seen in the mucopolysaccharidoses and related disorders.

In those patients old enough to cooperate with sensory testing, impaired sensation to pinprick and cotton wool was present despite the absence of parasthesiae. Tinel's sign was persistently negative.

The results of electrophysiological studies are shown in the table. Only patient 9 , aged 6 months at testing, had normal median nerve conduction. His older sibling (patient 10), had clear neurophysiological evidence of carpal tunnel syndrome at 1.7 years and it will be interesting to document the onset in patient 9 . Patient 4 was also slightly unusual in that her carpal tunnel syndrome was unilateral, affecting only the right hand (she is right handed). There was no clinical or neurophysiological evidence of other entrapment syndromes in any of the patients.

Decompression of the median nerve was performed by a longitudinal incision at the wrist in all patients except patients 1 and 11. At operation the flexor retinaculum appeared swollen in some patients; the nerve itself looked normal. Biopsy specimens of the flexor retinaculum were examined under the electron microscope. In all cases examined prominent lysosomal distension was seen within the fibroblast cell. Patients who have been operated upon have been followed up by regular electrophysiological testing. So far only patients 10 and 14 show improvement from their preoperative electrophysiological tests, both six months after operation. In contrast most patients and parents have reported symptomatic improvement in hand function. Detailed follow up studies of hand function in these patients are currently in progress.

\section{Discussion}

Carpal tunnel syndrome appears to be a common complication of the mucopolysaccharidoses and mucolipidosis III and is probably due to a combination of excessive lysosomal storage in the connective tissue of the flexor retinaculum as well as a deformed anatomy because of the underlying bone dysplasia. It occurs early in the course of the disorders and the long standing nature of the compression may explain the lack of typical symptoms in all the patients studied. This would also imply a poor response to surgical decompression and indicate the need to be aware of this possible complication in all patients with one of the mucopolysaccharidoses or mucolipidosis III. Those patients who have a mild variant need urgent diagnosis and treatment as the other complications of the disorders usually mean that in affected adults a clerical occupation, often requiring manual dexterity (for example, word processing) is the most suitable form of employment. In patients with severe variants of the mucopolysaccharidoses it is debatable whether or not the treatment of carpal tunnel syndrome justifies the risk of operation to release the nerve in a child whose life expectancy is very limited.

It is interesting to speculate why the bone marrow transplantation failed to prevent or reverse the carpal tunnel syndrome in patients 2 and 3 . It is likely that it was already present at transplant and the relatively avascular nature of the flexor retinaculum may make it difficult for donor enzyme to penetrate this dense connective tissue. In patients thought suitable candidates for bone marrow transplantation carpal tunnel syndrome should be sought and treated if present.

1 McKusick VA, Neufeld EF The mucopolysaccharide storage diseases. In: Scriver CR, Beaudet AL, Sly WS, storage diseases. In: Scriver CR, Beaudet AL, Sly WS, Valle D, eds. The metabolic basis of

2 Reitman ML, Varki A, Kornfeld S. Fibroblasts from patients with I-cell disease and pseudo-Hurler polydystrophy are deficient in uridine 5'-diphosphate- $\mathrm{N}$-acetylglucosamine. Glycoprotein $\mathrm{N}$-acetylglycosaminylphosphotransferase activity. $\mathcal{F}$ Clin Invest 1981;67:1574-9.

3 Kelly TE, Thomas GH, Taylor HA, et al. Mucolipidosis II (pseudo-Hurler polydystrophy): clinical and laboratory studies in a series of 12 patients. The fohns Hopkins Medical foumal 1975;137:156-75.

4 McArthur RG, Hayles AB, Gomez MR, Bianco AJ. Carpal tunnel syndrome and trigger finger in childhood. $A m \mathcal{F} D i$ Child 1969;117:463-9.

5 Fisher RC, Horner RL, Wood VE. The hand in mucopolysaccharide disorders. Clin Orthop 1974;104:191-9.

6 Karpati G, Carpenter S, Eisen AA, Wolfe LS, Feindel W. Multiple peripheral nerve entrapments. An unusual phenotype variation of the Hunter syndrome (mucopolysactype variation of the Hunter syndrome (mucopolysac-
charidosis II) in a family. Arch Neurol 1974;31:418-22.

7 Swift TR, McDonald TF. Peripheral nerve involvement in Hunter syndrome (mucopolysaccharidosis II). Arch . Neurol Hunter syndrom

8 Miner ME, Schimke RN. Carpal tunnel syndrome in paediatric mucopolysaccharidoses. Report of four cases. f Neurosurg 1975;43:102-3.

9 MacDougal B, Weeks PM, Wray RC. Median nerve compression and trigger finger in the mucopolysaccharidoses and related diseases. Plast Reconstr Surg 1977;59:250-63.

10 Saino K, Merikanto J, Larsen TA. Carpal tunnel syndrome in childhood. Dev Med Child Neurol 1987;29:784-804.

11 Cruz Martinez A, Perez Conde MC, del Campo F, Barrio M, Gutierrez AM, Lopez E. Sensory and mixed conduction velocity in infancy and childhood. 1 . Normal parameters in median, ulnar and sural nerves. Electromyogr Clin Neurophysiol 1978;18:487-504. 